\title{
Jejak Relasi Agency-Struktur dalam Perjalanan Pers di Indonesia
}

\author{
Susilastuti DN, Hermin Indah Wahyuni dan Munawar Akhmad \\ Jurusan Ilmu Komunikasi Fisip UPN "Veteran” Yogyakarta \\ Jurusan Ilmu Komunikasi Fisipol UGM \\ Jurusan Sosiologi Agama, Fakultas Ushuluddin dan Pemikiran Islam UIN 'Sunan Kalijaga \\ Yogyakarta \\ Email: susilastuti@gmail.com \\ Email: herminkilo12@gmail.com \\ Email: munawar.ahmad@uin-suka.ac.id
}

\begin{abstract}
:
Journalist relations as an agency with a structure sometimes cause resonance and irritation raising contentious between the two. The situation explains the position of journalists as an agency that is always actively responding to the structure, especially in relation to public interest policy. The liveliness of journalists does not aim to overthrow the structure but only cause contentiousness. The relationship can be found through journalistic journalism. The research approach is qualitatively critical. The assumption is that journalists are not only formed by structures outside themselves, but journalists have the autonomy to respond to existing structures with due regard to the historical, social, cultural and political economic context. Data analysis by performing document search, journalist relation with power structure done since Dutch colonial era until reform era. The response given by the power structure can be in the form of persuasive, repressive, journalist imprisonment and revocation of press release letters where journalists work. The conclusion of this research is the activity of journalists as the agency basically to provide sufficient information to the public so as to create information democracy. The structural responses related to the liveliness of journalists in each era have the same pattern of persuasion, level of tension and level of repression.
\end{abstract}

Keywords: Relationships, contentious, journalists, power structures, tactics

\begin{abstract}
Abstrak
Relasi wartawan sebagai agensi dengan struktur adakalanya menimbulkan resosansi dan menyebabkan iritasi sehingga menimbulkan ketegangan antar keduanya. Situasi tersebut menjelaskan posisi wartawan sebagai agensi yang senantiasa aktif merespon struktur, terutama terkait dengan kebijakan yang menyangkut kepentingan publik. Keaktifan wartawan tidak bertujuan untuk menjatuhkan struktur tetapi hanya menimbulkan ketegangan (contentious). Relasi tersebut bisa ditemukan melalui karya jurnalistik wartawan. Pendekatan penelitian adalah kualitatif kritis. Asumsinya bahwa wartawan tidak hanya terbentuk oleh struktur di luar dirinya, namun wartawan mempunyai otonomi untuk merespon struktur yang ada dengan memperhatikan konteks historis, sosial, budaya dan situasi ekonomi politik. Analisa data dengan melakukan penelusuran dokumen, relasi wartawan dengan struktur kuasa dilakukan sejak jaman penjajahan Belanda hingga era reformasi. Respon yang diberikan struktur kuasa bisa dalam bentuk persuasif, represif, pemenjaraan wartawan dan pencabutan surat ijin penerbitan pers dimana wartawan bekerja. Kesimpulan dari penelitian ini
\end{abstract}


keaktifan wartawan selaku agensi pada dasarnya untuk memberikan kecukupan informasi kepada masyarakat sehingga tercipta demokrasi informasi. Respon struktur terkait keaktifan wartawan di masing-masing era memiliki pola yang sama yaitu level persuasi, level ketegangan dan level represi.

Kata kunci: Relasi, ketegangan, wartawan, struktur kuasa, siasat

\section{Pendahuluan}

Wartawan adalah agensi yang senantiasa aktif merespon struktur melalui tulisannya. Keterlibatan wartawan ini tidak semata-mata didorong oleh keinginan menjatuhkan rezim yang berkuasa, tetapi tulisannya untuk membela kepentingan publik. Tulisan tajam wartawan menyebabkan terjadinya resonansi dan iritasi sehingga terjadi ketegangan (contentious) dan mendorong struktur kuasa meresponnya. Wartawan sebagai agensi akan bereaksi menuliskan fakta-fakta ketika struktur kuasa melakukan abuse of power, arbitary. Ketika menuliskan hal itu wartawan harus memiliki siasat karena ia bekerja di institusi pers yang memiliki ideologi tertentu.

Jejak ketegangan (contentious) wartawan dan struktur kuasa bisa dilacak sejak jaman penjajahan Belanda hingga saat ini. Walaupuan konteks sosial politik yang melatar belakangi timbulnya ketegangan di setiap era tidak sama. Namun semua bermuara ketika struktur kuasa melakukan abuse of power, arbitary dan merugikan kepentingan publik. Reaksi struktur kuasa bisa pada level persuasi, represi, hingga berujung pada tuntutan hukum. Respon struktur dalam setiap level ini berproses sesuai dengan kondisi sosial politik pada masanya.

Tidak jarang, tulisan wartawan yang tajam menyebabkan institusi tempat wartawan bekerja dibreidel oleh struktur kuasa karena dianggap tidak sejalan dengan kebijakan pemerintah, menganggu stabilitas nasional dan lainnya. Namun hal itu tidak menyurutkan marwah wartawan sebagai agensi untuk menggunakan penanya membela kepentingan publik.
Bagaimana reaksi struktur terhadap tulisan wartawan di setiap era berbeda-beda, salah satunya dengan menggunakan regulasi yang menyangkut tentang pers. Misalnya, pada masa Orde Baru, misalnya, regulasi tentang pers yaitu Undang-undang No 11 Tahun 1966 diubah menjadi Undang-undang No 21 Tahun 1982 menjadi alat untuk mengatur hingga merepresi wartawan serta instiusi tempatnya bekerja. Hal ini disebabkan regulasi pers pada masa Orde Baru memberikan ruang kepada struktur melakukan pembredelan institusi pers karena memuat tulisan wartawan yang dinilai tidak sejalan dengan kepentingan struktur kuasa.

Banyak contoh tentang hal itu, misalnya pencabutan Surat Ijin Terbit (SIT) harian Sinar Harapan 2 Januari 1973 karena dituduh telah membocorkan rahasia negara yaitu menyiarkan isi RAPBN 1973-1974 sebelum pemerintah mengumumkan secara resmi. Peringatan Kopkamtib kepada Pos Kota, Kami dan Merdeka agar tidak lagi menyiarkan intrik-intrik politik yang tidak benar (Ahmad Zaini Akbar, 1995).

KasusterbunuhnyawartawanBernasFuad Muhammad Syafruddin atau Udin yang diduga karena tulisan-tulisannya kritis tentang struktur kuasa di Kabupaten Bantul di era itu. Kasus ini setelah 20 tahun juga belum bisa dituntaskan dan masih menyisakan tanda tanya siapa yang berada di belakang kematian Udin, apa motivasinya. Keterlibatan aktif agensi menyebabkan skenario rekayasa bahwa kematian Udin karena persoalan pribadi dipatahkan, walaupun Dwi Sumadji alias Iwik sempat menjadi kambing hitam walaupun kemudian dibebaskan demi hukum.

Sejak jaman penjajahan Belanda hingga bangsa Indonesia memasuki era reformasi 
tindakan represi struktur terhadap wartawan dan institusi tempatnya bekerja mengalami pasang surut. Namun ketika Orde Baru jatuh ada angin keterbukaan dan memberikan ruang yang lebih luas kepada wartawan selaku agensi menjalankan peran fungsinya. Jaminan itu tertuang dalam Undang-undang No 40 Tahun 1999 tentang Pers yang disyahkan tanggal 23 September 1999.

Regulasi ini memberi wartawan ruang yang luas untuk mencari fakta sehingga euforia wartawan dalam menjalankan peran dan fungsinya. Bisa dikatakan wartawan selaku agensi merespon secara dinamis dan cepat peristiwa politik yang di rezim sebelumnya tabu untuk diekspose. Keberanian wartawan juga diikuti dengan keberanian masyarakat (individu, organisasi masyarakat dan lainnya) merespon hasil tulisan wartawan sehingga gesekangesekan yang terjadi tidak hanya dalam tataran wartawan dengan struktur, tetapi wartawan dengan masyarakat.

Perubahan politik juga berdampak terhadap dinamika masyarakat, negara atau institusi terhadap tulisan wartawan. Tulisan wartawan menyebabkan masyarakat bergerak lebih cepat dari sebelumnya. Informasi merupakan isi dari media cetak menghantarkan masyarakat menjadi komunitas yang iterasi, paham dan mengerti tentang fenomena yang terjadi di lingkungannya.

Jejak perjalanan wartawan untuk merespon struktur yang kurang berpihak kepada kepentingan publik sudah dimulai sejak jaman penjajahan Belanda hingga saat ini. Wartawan senantiasa bergerak aktif untuk merespon struktur kuasa yang ada di luar dirinya digerakkan oleh tujuan menjalankan hak masyarakat untuk mendapatkan informasi. Wartawan pada dasarnya menjalankan salah satu hak dasar manusia yaitu hak mendapatkan informasi (Susilastuti, 2002).

Melihat relasi agensi dengan struktur kuasa yang terjadi di satu negara pada dasarnya bisa menjadi tolok ukur terjadinya demokrasi. Agensi dalam tulisan ini adalah wartawan. Struktur kuasa dalam konteks tulisan ini adalah pemerintah yang mempunyai legitimasi dan wewenang mengatur kepentingan publik.

Wartawan tidaklah bekerja dalam ruang yang kosong, ada nilai-nilai dalam diri wartawan yang mendorongnya merespon satu fakta dan peristiwa dalam masyarakat. Wartawan tidak bisa lagi mengganggap bekerja di ruang hampa yang hanya sekedar memotret fakta, atau angkat tangan kalau terjadi apa-apa. Wartawan mempunyai peran dalam memilih fakta, narasumber yang akan dipilih sebagai bahan berita. Siapa dan apa yang akan dipilih wartawan sangat tergantung pada nurani wartawan (Sirikit Syah, 2011).

Wartawan aktif merespon struktur di luar dirinya dan menuliskannya dalam bentuk berita, merujuk kepada kepentingan public. Sebagaimana dikemukakan oleh Ricard Kaeble dalam pengantar bukunya Etics for Journalist (Ricard Karble,2010).

"....But the essential message of the text remains the same: the basic roles of the journalist are to promote peace and understanding, to work with honesty, clarity and compassion, to give voice to the voiceless, the desperately poor, the oppressed; to challenge stereotyping and expose corruption and lying - and to respect diversity and difference" (Tapi pesan penting dari teks tetap sama : peran dasar wartawan adalah untuk mempromosikan perdamaian dan pemahaman, untuk bekerja dengan kejujuran, kejelasan dan kasih sayang, untuk memberikan suara untuk yang sangat miskin, yang tertindas ; untuk menantang stereotip dan mengekspos korupsi dan berbohong dan menghormati keragaman dan perbedaan)

Wartawan ketika aktif merespon strukrur akan berhadapan dengan struktur kuasa di luar dirinya maupun internal tempat ia bekerja (news room). Melalui otonomi yang dimilikinya wartawan memiliki kebebasan untuk menuliskan fakta dan peristiwa (William R Rivers, Jay W Jensen, Theodore Paterson, 2004).

Namun persoalan yang sering dihadapi wartawan untuk bisa merespon struktur adalah bersikap obyektif. Obyektvitas terdiri 
dari dua dimensi, pertama, faktualitas yaitu usaha mencari kebenaran atau truth. Dimana berita harus harus relevan dengan pembaca, mempunyai nilai berita. Kedua, impartialitas mengacu pada praktek-praktek jurnalistik yang mengedepankan balance, non partisantship dan neutral presentation. Balance berarti ada unsur keadilan dan keseimbangan dalam pemberitaan. Neutralitas berarti tidak membangun opini untuk kepentingan tertentu. Obyektivitas dalam jurnalisme tidak mungkin mencapai tingkat yang sempurna 100 persen (Amir Efendi Siregar, 2015).

Keaktifan wartawan merespon struktur pada dasarnya menempatkan wartawan sebagai agensi. Agensi tidak mengacu kepada maksud yang dimiliki orang ketika melakukan sesuatu (karena agensi mengandung kuasa). Agensi berkaitan dengan kejadian yang melibatkan individu itu sebagai pelaku. Artinya individu dapat bertindak berbeda dalam setiap fase apapun. Agensi mempunyai kemampuan mempengaruhi rangkaian peristiwa atau keadaan yang ada di sekitarnya (Anthony Giddens, 2010).

Kekuasaan dalam sistem sosial memiliki kontinuitas di sepanjang ruang dan waktu dengan mengandaikan rutinitas relasi-relasi kemandirian dan ketergantungan di antara para aktor dan kelompok dalam konteks sosial. Agensi melalui tindakan yang diambilnya akan mempengaruhi kekuasaan yang dijalankan oleh orang lain. (Anthony Giddens, 2010).

Wartawan sebagai agensi akan selalu secara kontinu aktif merespon struktur di luar dirinya. Respon wartawan ini dituangkan dalam bentuk tulisan yang disebut berita.berita. Berita yang ditulis wartawan bisa berita straight news, feature, indepth reporting. Tulisan wartawan tidak selamanya berjalan paralel dengan kepentingan struktur.

Tatkala struktur dengan legitimasi dan wewenang yang dimiliki merugikan kepentingan publik, wartawan akan meresponnya. Respon wartawan dalam tulisannya bisa jadi meminta penjelasan kepada struktur atas tindakannya yang merugikan kepentingan publik. Ketika relasi tidak berjalan paralel maka akan memunculkan ketegangan (contentious) antara wartawan dan struktur.

Respon struktur struktur bisa pada level persuasif, level ketegangan atau level represif. Lompatan respon dari persuasif dan represif bisa berlangsung lama atau cepat sangat tergantung bagaimana wartawan menuliskannya. Namun dalam relasi ini wartawan tidak berkeinginan bermaksud menjatuhkan sebuah rezim tapi membuka ruang diskursus atas persoalan yang merugkan publik.

Bagaimana ketegangan (contentious) struktur yang disebabkan oleh tulisan wartawan dalam setiap episode waktu memang berbedabeda. Teori ketegangan (contentious) politik (Charles Tilly, Sidney Tarrow, Doug, McAdam, 2007) sebenarnya adalah upaya membangun sintesis atas berseraknya studi tentang pertentangan dan tindakan kolektif melalui upaya untuk membangun narasi dari tiaptiap episode pertentangan untuk menemukan berbagai mekanisme dan proses yang mendorong tindakan-tindakan ketegangan untuk dikaitkan dengan awal kemunculan dan capaian-capaian tindakan tersebut. Teori ketegangan politik (Contentious Politic) merupakan sebuah teori yang ingin menggabungkan berbagai studi yang terfragmentasi dalam isu pertentangan, politik, tindakan kolektif dan gerakan sosial.

Politik ketegangan (Charles Tilly, Sidney Tarrow, Doug, McAdam,2007) sebagai: "interaksi kolektif secara episodik dan publik, di antara para pembuat klaim dan obyeknya, ketika (a) pemerintah paling tidak menjadi pihak pengklaim, obyek yang diklaim atau bagian dari pengklaim, dan (b) klaim-kalim tersebut akan mempengaruhi kepentingan paling tidak salah satu pembuat klaim". Tulisan wartawan dalam bentuk berita yang merupakan respon aktif terhadap struktur bisa menimbulkan ketegangan (contentious) dan saling klaim atas fakta yang telah ditulis tersebut.

Respon wartawan terhadap struktur kuasa yang diwujudkan melalui tulisannya menjadi informasi bagi sub sistem dalam sistem secara 
keseluruhan. Informasi ini akan membantu masing-masing sub sistem untuk untuk beradaptasi terhadap perubahan sistem secara keseluruhan. Tatanan sosial itu akan membentuk atau mengembangkan sistem sosial. Sementara jurnalisme adalah rumah dengan banyak kamar dengan keragaman identitas (Nico Carpentier, 2016)

Berdasarkan kerangka pemikiran tersebut, maka relasi wartawan dan struktur ingin melihat bagaimana wartawan sebagai agensi melakukan respon terhadap struktur kuasa yang dinilai telah melakukan abuse of power, arbritary sehingga kepentingan publik terganggu. Keaktifan wartawan ini tidak dalam kerangka menjatuhkan struktur kuasa tapi menimbulkan resonansi dan menyebabkan iritasi yang menuntut respon dari struktur.

\section{Metode Penelitian}

Penelitian ini merupakan penelitian kualitatif dengan pendekatan kritis (critical theory). Hal ini didasarkan pada asumsi bahwa wartawan tidak hanya terbentuk oleh struktur di luar dirinya, namun wartawan mempunyai otonomi untuk merespon struktur yang ada dengan memperhatikan konteks historis, sosial, budaya dan situasi ekonomi politik.

Penelitian untuk melihat keaktifan wartawan merespon struktur yang ada menggunakan pendekatan kritis dengan melihat konteks sosial dan politik ketika wartawan selaku agensi bekerja merespon strukur. Fakta, mencerminkan atau refleksi dari kepentingan kekuatan dominan.

Pengumpulan data melalui studi dokumen. Studi dokumen ini akan dilakukan untuk bertujuan untuk mencari penjelasan atas hasil penafsiran atas teks dengan praktek sosiokultural tempat suatu media berada dilakukan untuk melacak keaktifan wartawan merespon struktur. Studi dokumen dilakukan dengan menelusuri literatur-literatur yang mengkaji pers pada umumnya, serta media pada umumnya. Penulusuran juga dilakukan melalui peneusuran tulisan-tulisan wartawan yang relevan dengan tulisan ini,

Wawancara dilakukan kepada (a) wartawan senior yang terlibat gerak wacana di Jaman Belanda hingga era reformasi. Wawancara mendalam dilakukan dengan membuat pertanyaan terstruktur terkait dengan bagaimana pertarungan di ruang newsroom dan struktur kuasa ketika akan menulis informasi menjadi berita. Reabilitas penelitian dilakukan dengan mendiskusikan temuan penelitian dalam diskusi terbatas dengan wartawan-wartawan yang di masing-masing era sehingga bisa mendapatkan analisis yang kritis.

\section{Hasil Penelitian dan Pembahasan Jejak Ketegangan Wartawan di Indonesia}

Wartawan melalui tulisannya telah memainkan peran dalam perjalanan sejarah bangsa Indonesia. Wartawan berjuang melalui penanya. Konsekuensinya wartawan akan menghadapi sikap represi dari struktur kuasa yang berujung pada pemenjaraan dirinya atau bahkan nyawa menjadi taruhannya. Institusi tempatnya bekerja juga mendapatkan imbas dari tulisan wartawan mulai dari peringatan hingga pada pelarangan media itu terbit.

Konsekuensi tersebut tidak menyurutkan wartawan untuk senantiasa aktif merespon struktur. Dalam studi literatur kita bisa melacak sepak terjang wartawan yang keluar masuk penjara akibat tulisannya atau sikapnya ketika berhadapan dengan struktur. Seperti Rosihan Anwar, Mochtar Loebis, Atmakusumah, Fuad Muhammad Syafruddin dan masih banyak lagi.

Pada di jaman penjajahan Belanda dan Jepang cukup banyak wartawan ketika membangun relasi dengan struktur mnyebabkan ketegangan (contentious) seperti Trito Adhi Suryo, Abdul Rivai. Belanda pernah menyekap wartawan-wartawan yang aktif merespon struktur antara lain Ir Taher Tjandrabumi, Samawi, SK Trimurti, Adam Malik dan lainnya. Ir Taher Tjandrabumi dihukum Belanda karena tulisannya tentang pemberontakan di kapal De Zeven Princien (Tribuana Sahid, 1998).

Pada jaman Jepang wartawan Indonesia 
menghadapi persoalan yang jauh lebih sengsara di satu sisi, tetapi juga mendapatkan ilmu tentang pengelolaan pers di sisi lain. Masa penjajahan Jepang semua kendali diambil alih oleh Jepang dan dikontrol oleh petugas Domai. Isi pers semua untuk memenangkan "Perang Asia Timur Raya”. Situasi tersebut tetap tidak menyurutkan wartawan untuk merespon struktur yang menindas masyarakat serta mengobarkan semangat kemerdekaan pada masyarakat Indonesia. Bisa dicatat beberapa wartawan yang ditangkap dan dihukum pemerintah Jepang antara lain, Anomputra yang dibunuh karena dinilai telah melakukan penghasutan, RM Winarno, Mr Sumanang dan lainnya (Tribuana Said, 1998).

Setelah Indonesia merdeka wartawan tetap aktif merespon struktur. Pada masa jaman penjajahan wartawan Indonesia berhadapan dengan penjajah, setelah merdeka berhadapan dengan struktur kuasa yang dulu juga berjuang bersama mengusir penjajahan.

Berdasarkan kajian literatur, kita bisa memilihkan relasi wartawan selaku agensi dengan struktur dalam beberapa episode yaitu (1) Pemerintah Orde Lama pada awal kemerdekaan, (2) Pemerintah Orde Lama pada masa demokrasi terpimpin, (3) pemerintahan Orde Baru (4) Pasca Orde Baru. Fase-fase ini membantu memudahkan bagaimana pasang surut relasi agensi dan struktur kuasa, serta konsekuensi logis yang harus ditanggung wartawan serta institusi tempatnya bekerja.

Pada awal kemerdekaan bisa dikatakan merupakan masa-masa bulan madu wartawan dan struktur. Keduanya mempunyai tujuan yang sama yaitu bagaimana mencegah intervensi asing ke Indonesia seperti agresi Belanda I dan agresi Belanda II, serta mengobarkan semangat mempertahankan kemerdekaan pada masyarakat. Tulisan wartawan mendorong masyarakat, strukrur berjuang mempertahankan kemerdekaan. Tulisan wartawan di media-media pribumi menjadi counter isu atas propaganda Sekutu yang ingin menguasai lagi Indonesia. Hal ini tentu berdampak pada wartawan serta institusi tempatnya bekerja. Salah satu contohnya
Idroes Nawawi, RA Hakky, Kahman Thalib, BM Diah Herawati ditahan tentara Nica.

Ketika persoalan membendung intervensi asing yang akan masuk ke Indonesia sudah tidak lagi menjadi isu utama, wartawan tetap aktif merespon struktur terutama terkait dengan penyalahgunaan wewenang, sikap otoriter struktur di semua level kehidupan sosial politik, serta perilaku yang menyimpang dari norma dan tata kesusilaan. Ketika ranah ini menjadi fokus yang direspon wartawan, maka relasi yang harmonis antara wartawan dan struktur mulai retak.

Struktur yang mulai kuat menggunakan legitimasi dan wewenangnya untuk melakukan represi terhadap wartawan dan media tempatnya bekerja. Pada masa Orde Lama wartawan senior yang tulisannya serimgkali direspon struktur adalah wartawan Indonesia Raya Mochtar Lubis. Kekritisannya dalam menghadapi struktur kuasa di era Orde Lama menyebabkan ia sering di penjara oleh penguasa. Kesanggupan Mochar Lubis untuk dikenai tahanan rumah atau dipenjara demi prinsipnya pers menyebabkan wartawan generasi dibawahnya menujuliki sebagai penjelmaan jihad untuk kemerdekaan pers (Atmakusumah, 1992). Ia menyebut Mochtar Lubis memberikan sumbangan bermakna bagi pembangunan adab dan pembentukan sistem politik di Indonesia. Kajian tentang hal ini bisa dilacak dari penelitian David T Hill (2010) melakukan kajian terhadap wartawan senior Mochtar Lubis, mencoba melihat sepak terjang Mochtar Lubis sebagai wartawan sekaligus sebagai pimpinan redaksi Harian Indonesia Raya.

Mantan wartawan Indonesia Raya yang sampai saat ini masih aktif menulis yaitu Atmakusumah Astraatmadja mengemukakan, Mochtar Lubis memberikan ruang gerak yang luas kepada wartawan untuk menuliskan fakta dan peristiwa di masyarakat. Wartawan dituntut untuk selalu kritis apapun kondisinya," Atmakusumah (wawancara, di Jakarta, 19 April 2016)

Kekritisan wartawan dalam menyoroti kebijakan pemerintah Orde Lama juga bisa dilihat dalam tulisan wartawan hasil wawancara dengan Bung Tomo yang dimuat dalam surat 
kabar DAG Bladvoor Zeuid Sumatera (1 Juni 1950) yang menyoroti industri yang tidak efisien serta korupsi dengan judul "Het Kolonialism onder de eigen mensen". Salah satu kutipan tulisan wartawan "....de nationalastie der bedrijven kan hij niet goodkeuren, sangezien industrie in regeringshanden minder efficient werkt en de corruptie in de hand werkt, waardoor geen winat ult deze bedrijven is te verwachten...."

Pada masa demokrasi terpimpin bisa dikatakan sebagai periode hitam bagi wartawan dan pers di Indonesia. Wartawan dan pers tempatnya bekerja dijadikan alat untuk mendukung ideologi penguasa, bisa dicermasi dikeluarkannya regulasi yaitu Pedoman Penguasa Perang Tertinggi untuk pers Indonesia tanggal 12 Oktober 1960 (Akhmad Zaini Akbar 1995). Bahkan surat kabar harus berafiliasi pada partai politik tertentu, misalnya Duta Masyarakat (Nadathul Ulama), Abadi (Masyumi), Suluh Indonesia (PNI) dan lainnya.

Situasi sosial politik yang semakin mempersempit gerak wartawan selaku agensi untuk merespon perilaku struktur menyebabkan wartawan harus memiliki siasat atau taktik ketika berhadapan dengan struktur. Contohlah, Rosihan Anwar ia merespon perilaku struktur tidak ada hubungannya dengan kebijakan politiknya, tetapi perilaku struktur yang dinilai kurang tepat. Rosihan Anwar menulis di harian Pedoman tentang perilaku Presiden Soekarno yang akan menikahi Hartini, kritikannya tidak dikehendaki Soekarno sehingga harian Pedoman ditutup untuk selama-lamanya (Priyambodo (ed), 2013).

Kejatuhan Soekarno tidak bisa dikatakan disebabkan tulisan wartawan karena respon wartawan sebagai agensi terhadap struktur bukan untuk menggulingkan. Namun tulisan itu, wartawan membuka cara berpikir masyarakat untuk melihat ada yang kurang tepat dari struktur dalam membuat kebijakan untuk kepentingan publik.

Relasi wartawan, serta institusi tempatnya bekerja dengan struktur kuasa yang harmonis juga terjadi di awal-awal pemerintahan Orde Baru. Kritikan-kritikan direspon secara persuasif, bahkan ketika struktur kuasa mengeluarkan regulasi tentang pers yaitu Undang-undang Nomor 11 Tahun 1966 yo UU No 11 Tahun 1967 tentang Ketentuan Pokok Pers wartawan tetap diberi ruang untuk mengkritisi stryktur selama tidak menyingsung persoalan komunisme dan tidak bertentangan dengan Pancasila dan isu SARA.

Bisa dikatakan regulasi baru tidak dijadikan alat penguasa walaupun wartawan aktif dan kritis menyoroti kebijakan-kebijakan pemerintah Orba. Misalnya saja, tulisan yang dimuat di Harian Indonesia Raya terkait pembantaian massal tahanan politik di Purwodadi (wawancara dengan Atmakusumah, 2016).

Seiring berjalannya waktu struktur kuasa mulai gerah dengan keaktifan struktur. Respon persuasif berubah memunculkan ketegangan yang ditandai peringatan-peringatan lisan pada media yang memuta tulisan wartawan yang dinilai tidak sejalan dengan struktur setelah itu respon struktur mulai represif. Tulisan wartawan Sinar Harapan tahun 1973 yaitu dugaan pembocoran rencana anggaran belanja negara. Tulisan ini menyebabkan Sinar Harapan mendapatkan peringatan keras dan menyebabkan izin terbitnya dicabut oleh struktur kuasa.

Jendral Sumitro: Nasib "SH” Ditentukan Hasil2 Pemeriksaan: Tiga Koran Lagi Dapat Peringakatan; Jakarta, Jumat

“.... Seandainya pemeriksaan menunjukkan adanya kaitan pembocoran rencana anggaran belanja negara oleh Sinar Harapan dengan suatu opsi tertentu maka mungkin saja izin terbit Sinar Harapan dapat dicabut pula..."(Harian Indonesia Raya, 5 Januari 1973)

Tulisan wartawan tentang peristiwa Malari (Malapetaka Lima Januari) 1974 membawa imbas luar biasa sehingga menyebabkan ketegangan dengan struktur kuasa. Akibatnya struktur kuasa merespon bahasa politik yang tajam dari wartawan dan berujung pada peringatan lisan kemudian pembredelan. Tulisan-tulisan 
wartawan menekankan aksi demonstrasi yang dilakukan mahasiswa bersamaan dengan kedatangan Perdana Menteri Jepang Tanaka ke Indonesia. (Sinar Harapan, 15 Januari 1974).

Appel Siaga 12 Dewan Mahasiswa: $P a-$ tung "Imperialis Ekonomi” dan "Anjing Tokyo" Dibakar.

"... "Appel Siaga" Mahasiswa dan Pelajar Ibukota yang disemarakkan dengan lagu top hit 1974, pembakaran Patung "Imperialis Ekonomi" dan "Anjing Tokyo" Dibakar dan deklarasi berlangsung Sabtu pagi di Kampus UKI Jakarta....tidak ketinggalan petugas intel yang "nimbrung"...." (Sinar Harapan, 14 Januari 1974, hal.1) “

Meskipun baru saja setahun setelah SITnya dicabut oleh struktur kuasa, tidak menyurutkan wartawan media ini bersikap tajam dalam menuliskan fakta yang berkaitan dengan struktur kuasa. Tulisan wartawan yang dimuat diberbagai media massa terkait kasus Malari 1974 direspon sangat keras oleh struktur kuasa. Hal ini bisa dilihat dari berita di bawah ini

Hasil Sidang Kabinet Terbatas :

ENAM LANGKAH UNTUK JAMIN STABILISASI

“.... Langkah-langkah yang perlu diambil menertibkan pemberitaan 2 pers maupun surat kabar...." (Sinar Harapan 18 Januari 1974).

Salah satu korban adalah pencabutan SIT "Nusantara" yang dinilai telah memberitakan fakta-fakta yang tidak mendasar. "....surat kabar Nusantara telah melanggar semangat daripada ketentuan yang telah melanggar semangat daripada ketentuan2 yang tercantum dalam TAP No IV/MPR/1973 tentang GBHN dan UU No 11 Tahun 1966 tentang pers. ... surat kabar Nusantara juga dinilai menyiarkan tulisan yang tidak mendasarkan pada kebenaran dan yang dapat menghasut rakyat untuk mengambil tindakan2 yang mengganggu ketertiban dan keamanan negara..."(Sinar Harapan 18 Januari 1974).
Puncaknya, struktur kuasa meninjau kembali regulasi tentang pers yaitu disyahkannya UU Nomor 21 Tahun 1982 tentang Ketentuan Pokok Pers. Regulasi ini pada intinya memberikan peluang pada struktur masuk mengatur pers, melakukan represi terhadap pers dengan ancaman pencabutan Surat Ijin Usaha Penerbitan Pers (SIUPP). Misal, Menpen menjadi ex officio Ketua Dewan Pers. Padahal menurut regulasi baru tersebut, pemerintah ketika akan mencabut SIUUP akan meminta persetujuan Dewan Pers.

Wartawan selaku agensi tetap bisa bekelit untuk bisa keluar dari tekanan struktur atau ketatnya ketentuan di newsroom. Mantan wartawan Jakarta-jakarta Stabley Adi Prasetyo mengatakan, bahwa di era Orde Baru wartawan harus bisa mengatur siasat agar tulisannya bisa lolos dari ketatnya seleksi di tingkat newsroom. Siasat yang dilakukan adalah menyerahkan tulisan menjelang deadline. Puncak ketenggangan di newsroom adalah menjelang deadline sehingga seringkali kontrol atas tulisan agak mengendur (Wawancara, 2016).

Peristiwa fenomenal terkait represi struktur adalah pembredelan Majalah Tempo, Editor, Detik tahun 1994. Pembredelan Tempo terkaitu tulisan, namun tidak ada penjelasan secara tegas dari struktur tentang tulisan yang dimaksud, sementara Detik, Editor lebih soal administrasi yang tidak sesuai undang-undang. Kemudian yangperistiwa fenomenal lain adalah terbunuhnya wartawan Bernas Fuad Muhammad Syafruddin (Udin) wartawan harian Bernas Yogyakarta dianiaya tanggal 13 Agustus 1995, meninggal tanggal 16 Agustus 1995.

Udin diyakini meninggal karena Berita, walaupun secara de jure maupun de facto tidak ada pengakuan dari struktur tentang penyebab kematian Udin hingga 20 tahun lebih setelah kasus itu terjadi. Tim Pencari Fakta (TPF) kasus Udin yang dibentuk oleh Persatuan Wartawan Indonesia (PWI) tempat Udin bergabung, meyakini bahwa kematian Udin disebabkan karena berita.

Ada 89 berita yang ditulis Udin dan diduga menimbulkan resonansi dan iritasi 
kemudiaan direspon struktur kuasa ada 89 berita yang terbagi dalam lima kelompok, (1) Mega Proyek Parangtritis (38 berita);(2) Pencalonan Bupati Bantul 1996-2001 (14 Berita), (3) setelah menjadi bupati ( 8 berita); (4) Masalah pertanahan (5 berita); (5) Berita-berita lain (24) Berita. ((Noorca M Marsaedi, 1997, Rusdi Marpaung, 199, wawancara, Asril Sutan Marajo, 2016)).

Penyebab kematian wartawan ini masih kabur. Namun salah satu tulisannya berhasil membuka tabir penyalahgunaan kekuasaan oleh Bupati Bantul waktu itu Sri Roso Sudarmo tentang janji uang kepada sebuah yayasan bila terpilih kembali . Hal ini dinilai menyalahi ketentuan sehingga ia divonis sembilan bulan penjara setelah melalui proses persidangan yang panjang di Mahkamah Militer Tinggi II/Semarang pada bulan Juli 1999 (Asril Sutan Marajo, 2007).

Tumbangnya rezim Orde Baru dan memasuki era reformasi perubahan yang signifikan adalah peninjauan kembali regulasi mengatur tentang pers. Disyahkannya UU No 40 Tahun 1999 menjadi babak baru relasi wartawan selaku agensi dan struktur karena regulasi ini "tidak ada" peluang bagi struktur melakukan breidel atau menghalang-halangi kerja wartawan.

Respon wartawan terhadap struktur di era ini memasuki tahapan baru yang dilabeli dengan "kebebasan yang kebablasan". Keberanian wartawan mengungkap fakta juga diberengi keberanian masyarakat dan struktur menggugat wartawan atau instusi pers yang memuat berita yang mereka nilai 'tidak benar". Keberanian masyarakat dan struktur diwujudkan dalam perilaku yang anarkis, kekerasan atau menempuh jalur hukum. Hal itu bisa dilihat dari pengaduan ke Dewan Pers. Data tahun 2012-2015 pengaduan kepada Dewan Pers mengalami peningkatan, ada 470 pengaduan (2012), 756 pengaduan (2013), 555 pengaduan (2014) dan 827 pengaduan (2015) (diolah dari data Dewan Pers).

Pasca Orde Baru atau yang lebih dikenal era reformasi, kajian-kajian tentang pers lebih dititikbeberatkan pada bagaimana pers memahami kebebasan. Selain itu juga banyak ditelaah tentang kekerasan yang dialami pers dalam men- jalankan tugas jurnalistiknya. Isu mengemuka di masa reformasi bagaimana wartawan dalam merespon struktur tetap mengacu pada kaidah atau norma, seperti Kode Etik Wartawan Indonesia, tidak boleh keluar dari bingkai yang bisa bersingkungan dengan persoalan hukum sebagaimana diatur dalam KUHP (delik penyiaran kaar bohong, asusila, pencemaran nama baik, penghasutan dan lainnya). Disisi lain juga dilakukan literasi media kepada masyarakat dan struktur tentang mekanisme yang harus ditempuh ketika tulisan wartawan tidak sesuai fakta.

Berdasarkan paparan di atas, jelaslah bahwa di setiap era relasi wartawan dan struktur mengalami pasang surut, Dalam proses produksi berita, wartawan menjadi kelompok yang paling strategis karena ia menjadi ujung tombak pertama ketika berhadapan struktur dan menuliskan fakta dan peristiwa dalam masyarakat. Ketidakmampuan wartawan merespon struktur akan berujung respon yang persuasig hingga penghukuman pada wartawan dan institusi tempatnya bekerja.

\section{Analisis Kritis}

Respon wartawan terhadap fakta dan peristiwa pada dasarnya sebagai manifestasi perwujudan pers tempatnya bekerja sebagai the four estate. Tulisan wartawan yang dimuat oleh pers tempatnya bekerja seringkali menimbulkan ketegangan (contentious) sehingga direspon oleh struktur. Wartawan pada dasarnya bekerja pada institusi pers yang merupakan institusi publik, dan merupakan caranya terlibat pada peri kehidupan publik (termasuk simpati pada persoalan politik) (Bagir Manan, 2014).

Tidak semua tulisan wartawan akan direspon oleh struktur. Demikian juga sebaliknya, tidak semua fakta dan peristiwa akan direspon wartawan. Ada kalanya wartawan akan mendukung struktur yang ada. Ideologi wartawan, kelompoknya, lingkungan tempatnya bekerja, sistem sosial politik serta aturan-aturan yang ada mempengaruhi bagaimana cara wartawan memberikan respon terhadap struktur.

Pers dimana wartawan bekerja pada dasarnya adalah tempat agensi dan struktur 
berkelahi. Wacana atau diskursus yang ditulis oleh wartawan akan direspon oleh pihak yang lain. Wartawan merekam, kemudian memproses berbagai fakta atau peristiwa yang dipadukan dengan berbagai pendapat bukanlah sekedar rangkaian kata-kata tetapi sebuah gagasan, konsep untuk merespon sebuah kondisi yang dipandang oleh wartawan "menyimpang". Peran inilah yang menyebabkan pers sering dijuluki sebagai four estate.

Pers sebagai four estate menurut Bagir Manan (2014) memang tidak menjalankan kekuasaan publik kenegaraan tetapi menjalankan fungsi untuk kepentingan publik. Titik temu antara pers dan negara adalah bersama-sama memikul tanggungjawab terhadap peri kehidupan publik. Dalam konteks Indonesia titik temu adalah tanggung jawab mencapai tujuan berbangsa dan bernegara yaitu mewujudkan kesejahteraan umum, mencerdaskan kehidupan bangsa, mencapai kemakmuran dan keadilan sosial bagi masyarakatnya.

Pers sebagai the four estate merupakan bagian dari sistem politik secara secara keseluruhan dan diposisikan sebagai infrastruktur politik yang menjalankan fungsi melakukan kontrol dan sosial, mengelola opini publik melalui berita-berita yang ditulis wartawan serta melakukan fungsi check and balance atas kekuasaan eksekutif, legislatif dan yudikatif. Intervensi wartawan ini akan membuka ruang demokrasi informasi bagi masyarakat.

Kontrol dan kritik yang dijalankan pers untuk menjaga akuntabilitas, serta untuk menghindari atau mencegah kesalahan dalam menjalankan pemerintahan. Fungsi kontrol dan kritik, seperti dikemukakan Bagir Manan (2014) bukan sekedar mencegah atau menghindari kesalahan , melainkan untuk mencegah atau menghindari penyalahgunaan kekuasaan (misused of power) dan kesewenang-wenangan (arbitrary).

Untuk menjalankan fungsi itu, wartawan menjadi ujung tombak karena wartawanlah yang akan berhadapan dengan struktur kuasa atau bersentuhan langsung dengan fakta dan peristiwa. Informasi-informasi inilah yang kemudian ditulis wartawan dan dimuat di media dimana mereka berkerja. Wartawan sebagai agensi akan selalu merespon struktur kuasa yang dinilai mengabaikan kepentingan publik. Sebagai agensi inilah yang menyebabkan tulisan wartawan bisa menimbulkan ketegangan (contentious) dengan struktur.

Ketegangan (contentious) yang dihasilkan melalui tulisan wartawan ini menyebabkan dinamika sistem dalam masyarakat berjalan. Tulisan wartawan menyebabkan adanya keterbukaan informasi dalam masyarakat. Keaktifan merespon struktur inilah yang menyebabkan wartawan menjalankan peran sebagai agensi.

Dalam menjalankan perannya sebagai agensi wartawan memiliki otonomi dalam keaktifan merespon struktur. Adapun otonomi tersebut yakni kebebasan dalam menulis, mengedit bahasa, mengambil sudut pijak (point of view), serta merumuskan kesimpulan berdasarkan berbagai pertimbangan otonomnya. Meskipun wartawan memiliki otonomi, newsroom dan pemilik media, memiliki peran penting melakuan setting dan sensoring terhadap tulisan wartawan (William R Rivers, Jay W Jensen, Theodore Paterson, 2004).

Tulisan wartawan diharapkan mendorong terwujudnya sebuah forum yang yang berorientasi kepada kepentingan publik dan bisa menjadi balancing information bagi struktur yang ada . Hal ini sebenarnya selaras dengan sembilan elemen jurnalistik, khususnya elemen yang keenam yaitu jurnalis harus memberi forum bagi publik (Bill Covach dan Tom Russel, 2001)

Informasi yang ditulis wartawan akan memberikan kesadaran publik untuk merespon struktur kuasa sehingga publik akan bisa beradaptasi dengan perubahan-perubahan itu. Semua informasi tidak hanya penting menambah pengetahuan publik, tetapi juga untuk membangun kesadaran dan tanggung jawab, serta mendorong kemajuan dan perubahan (information as a tool of change) (Bagir Manan, 2014). Pers bertanggungjawab di balik panggung kejadian untuk menyelidiki pekerjaan pemerintah. Pers harus menginformasikan mana yang berjalan baik 
dan mana yang tidak baik (Hikmat Kusumaningrat, 2007).

Tulisan wartawan dalam bentuk berita tadi dalam pandangan Luhmann (Alexander Gorke \& Armin Scholl, 2006) berkaitan dengan fungsi dalam sistem sosial yakni menyediakan masyarakat dengan berbagai informasi. Jurnalisme menurut Luhman dipandang sebagai institusi (sistem) yang otonom dari suatu masyarakat, yang tidak hanya menghantar informasi secara pasif, tetapi memunculkan informasi itu tergantung pada rules (aturannya) sendiri untuk menyediakan/memberikan orientasi kepada masyarakat. Hal ini selaras dengan yang dikemukakan Atmakusumah.

“...Arus informasi, memang, perlu dikelola secara bertanggung jawab agar bermanfaat dan bukan, sebaliknya, menyesatkan. Gagasan arus informasi seperti ini seharusnya juga berkembang di kalangan para pengelola media sosialyang, rupanya, banyak di antaranya tidak memahami etika bahwa ada keterbatasan dalam kegiatan berkomunikasi massa secara terbuka. Sama halnya seperti dalam profesi pers_-yang dibatasi oleh Kode Etik Jurnalistik atau Etika Pers, dan ini berlaku secara universal di seluruh dunia, terutama di Negara demokrasi..." (Atmakusumah, wawancara tertulis 10 Juni 2017).

\section{Simpulan}

Wartawan pada dasarnya agensi yang senantiasi aktif merespon struktur kuasa. Keantifannya didasarkan pada kenyataan bahwa struktur kuasa seringkali melakukan kebohongan, penyalahgunaan kekuasaan yang berdampak pada terganggunya kepentingan publik. Hasil dari keaktifannya merespon struktur kuasa bisa dilihat dalam karya jurnalistiknya.

Ketegangan (contentious) wartawan dan struktur kuasa, tujuannya tidak untuk menjatuhkan satu rejim. Tulisan wartawan menjadi penyeimbang kekuasaan, wartawan menjadi penggelitik agar sistem tidak terjebak pada hegemony atau oligarki. Informasi yang ditulis wartawan akan memberikan kesadaran publik untuk merespon struktur kuasa sehingga publik akan bisa beradaptasi dengan perubahanperubahan lingkungan sosial politiknya.

$$
\text { Keaktifan wartawan merespon }
$$

struktur kuasa pada dasarnya dalam kerangka memberikan kepada publik kecukupan informasi sehingga publik tidak hanya mendapatkan informasi yang single track information tapi multi track information. Adanya informasi yang favorable, maka wartawan akan menjadi penyangga terciptanya demokrasi informasi. Demokrasi tidak mungkin berkembang tanpa diberi "pupuk", antara lain berupa informasi yang dengan bebas mengalir di tengah masyarakattermasuk melalui media pers yang akurasi dan objektivitasnya dapat dipertanggungjawabkan oleh para pengelolanya. Dengan demikian, rakyat dapat memilah-milah informasi yang berguna bagi mereka untuk memperdalam pengetahuan yang dapat memajukan dan memperbaiki kehidupan mereka pada masa sekarang dan bagi keturunannya pada masa depan.

Pentingnya demokrasi informasi juga bisa merujuk pada deklarasi UNESCO antara lain memandang masyarakat agar mengenali etika berkomunikasi sebagaimana wartawan menulis di media massa. Media komunikasi massa yang profesional, sehingga isinya yang objektif dapat dipercaya, sangat penting agar dapat tetap terawat bersama-sama pengembangan demokrasi. Tujuannya adalah untuk mencegah dalih suatu kekuatan politik dalam pemerintahan untuk menekan kembali kebebasan berekspresi dan menyatakan pendapat serta kebebasan pers yang sekarang sedang berkembang. (Atmakusumah, 2017) Wartawan perlu merawat idelalismenya, profesionalisemenya agar perannya sebagai penjaga informasi tetap terjaga dengan baik.

\section{Daftar Pustaka}

Abar, Zaini, Akhmad, 1995, Kisah Pers Indonesia, 1966-1974, LkiS, Yogyakarta

Anwar, Rosihan, 2011, Sejarah Kecil Petite Histoire Indonesia, Jilid 3, Jakarta: PT 
Kompas Gramedia Astraatmadja, Atmakusumah,1999, Tuntutan Zaman Kebebasan Pers dan Ekspresi,Jakarta: Yayasan Tifa

Buguin, Burhan Buguin, 2005, Metodologi Penelitian Kuantitatif, Kencana, Jakarta. Carpentier, Nico, Journalism, Media, and Democracy, www. intellectbooks.co.uk/File:download, id.../9781841501635.151.pdf akses tanggal 16 April 2016

Giddens, Anthony, 2010, Teori Strukturasi : Dasar-dasar pembentukan struktur

Social masyarakat, terjemahan Maufur dan Daryatno, Yogyakarta: Pustaka Pelajar

Hill, T David, 2011, Pers di Masa Orde Baru, Jakarta: Yayasan Pustaka Obor.

--------, 2011, Jurnalisme dan Politik di Indonesia, Jakarta: Yayasan Obor

Karble, Richard, 2009, Ethics ofjournalist, British Library Cataloguing inPublication Data A catalogue record for this book is available from the British

Library Simultaneously published in the USA and Canada by Routledge 270

Madison Ave, New York, NY 10016 This edition published 2009 Routledge is an imprint of the Taylor \& Francis Group, an informa business (C) 2001

Kusumaningrat, Hikmat, 2007, Jurnalistik Teori dan Praktek, Remaja Rosda Karya, Bandung

McAdam. Doug, Charles Tilly, Sidney Tarrow, , 2007, "Comparative Perspectives

On Contentious Politics", dalam Alan Zuckerman (eds.), Comparative Politics:Rationality, Culture, andStructure: Advancing Theory in Comparative Politics,Cambridge: Cambridge University Press.

Manan, Bagir, 2014, Tantangan Pers Indonesia, Jakarta: Dewan Pers

Marajo, Sutan, Asril, 2007, Memburu Pembunuh Wartawan: Investigasi Kasus

Wartawan, Galang Press, Yogyakarta

Marpaung, Rusdi (ed), 1999, Kasus Udin:
Liputan Bawah Tanah, YLBH, Jakarta.

Masardi, Noorca, 1997, Udin Darah Wartawan:

Liputan Menjelang

Kematian, Pustaka Republika, Jakarta.

Nasir, Heidar, 2012, Memahami strukturisasi dalam perspektif sosiologis Giddens,

Jurnal Sosiologi Reflektif, Volume 7, Nomor 1, Oktober 2012

Priyambodo, dkk, 2013, Ensiklolopedi Pers Indonesia, PWI Pusat Jakarta

Oetama, Jacob, 1985, Apa Maunya Wartawan, dalam Bunga Rampai Catatan

Pertumbuhan Sistem Pers Indonesia, editor T Atmadi, Pantja Simpati

Peterson, Theodore, William R Rivers, Jay W Jensen, , 2004, Media Massa dan

Masyarakat Modern, Pernada Media, Jakarta

Rosentiels, Bill Kovach, 2001, Sembilan Elemen Jurnalistik, Pantau, Jakarta

Said, Tribuana, 1988, Sejarah Pers Nasional dan Pembangunan Pers Pancasila,Haji Masagung, Jakarta

Scholl, Armin, Alexander Gorke, " Niklas Luhmann's Theory of Social System an Journalism research", Journalism Studies, vol 7, no. 4, 2006

Siregar, Efendi, Amir , 2015, Meningkatkan Profesionalisme Wartawan : Bekerja untuk Publik dengan Obyektuif, Independen dan netral, Jurnal Dewan Pers, Edisi

No 11, Desember 2015.

Smith, C Edward C, 1983, Sejarah Pembredelan pers di Indonesia, Penterjemah,

Atmakusumah, Alex A Rachim, Arie Wikdjo Broto, Penerbit Grafitti, Jakarta

Susilastuti, 2002, Implementasi Kebebasan Pers di Indonesia (1990-2000), tesis, UGM

Surjohamihardjo, Abdurrahman (edt), 2002, Beberapa Segi Perkembangan Sejarah Pers di Indonesia, Kompas, Jakarta

Syah, Sirikit, 2011, Rambu-rambu Jurnalistik, Pustaka Pelajar, Yogyakarta 